\title{
Construction difficulties of training base in Higher Vocational Colleges and Countermeasures of Accounting Specialty
}

\author{
Hongling Lv \\ Economic and Trade Department \\ Zhengzhou Electric Power College \\ ShangCheng road No 2,zhengzhou city,china \\ lvfengshicheng@163.com
}

\author{
Xiangmei Xue \\ Economic and Trade Department \\ Zhengzhou Electric Power College \\ ShangCheng road No 2,zhengzhou city,china \\ xuexiangmei2011@sohu.com
}

\begin{abstract}
Practical teaching is the key to the development of vocational education, is the "core" and "breakthrough" of higher vocational education personnel training mode reform. And the construction of practical training base is the premise and guarantee of training education, China's higher vocational education training base construction after years of groping, what problems still exist, what new problems are developed, how to deal with these problems is very important.
\end{abstract}

Keywords-Higher Vocational Colleges; Accounting profession ; training base; Solution; Significance

\section{INTRODUCTION}

Always , practical teaching is the important Characteristic of higher vocational education, construction of training base is the important way to higher vocational colleges to improve the teaching quality and make the formation of school characteristics.

Many vocational colleges have emphasized the schoolenterprise cooperation school characteristics, increase the construction of training bases, but because of many factors, the current higher vocational accounting professional schoolenterprise cooperation and training base construction is facing many problems. Can be said that the construction of practice training base is a bottleneck in the present higher vocational education, So the vocational colleges must break the impasse to won a good social reputation for themselves if they want showing itself from many schools and improve their competitive ability to the students, improve their teaching awareness. This paper will discuss the accounting professional training base construction in Higher Vocational Colleges present problems and how to deal with the problems.

II. FACING THE ACCOUNTING PROFESSION IN VOCATIONAL COLLEGES TRAINING BASE CONSTRUCTION OF OUR COUNTRY'S DILEMMA

\section{A. Insufficient funds of the off-campus training bases, policy support is not enough.}

"The decision of the State Council in 2005 on the development of occupation education" And the Ministry of education "on improving the teaching quality of higher occupation education certain opinions" (high education [2006]16) and other documents, All that take the "school- enterprise cooperation, work-study combination" road. But the state has not promulgated policies and measures in this regard, no government department matchmaking for schoolenterprise cooperation. Education departments cannot provide essential help in addition to verbal encouragement of Higher Vocational Colleges school-enterprise cooperation, create a new mode of school-enterprise cooperation. At the same time, investment in construction of the off-campus training bases belong to the basic expenses, such as paying enterprise training fees, cannot form the school assets, not like the establishment of internal training room and equipment that can visible and tangible, which leads to the leaders of the higher vocational colleges in the school enterprise cooperation, the construction of training base outside the more attention to form, don't focus on substance. Only pay attention to all the teaching system and how many units have signed a cooperation agreement and the construction of practice training base agreement, but does not care about these units is be worthy of the name of the training base. For example, the writer's school and one Financial Management Company Limited signed a long-term agreement listing training base training, Every year , The third grade students enter into the management company to practice, school funding provisions in each student 8 yuan every day, In 2012, as prices rise every day life up to 10 yuan, but such a limited practice funds simply can not afford to mobilize of the company, often a group of ten people send a training teachers, and the teachers also does not have the practical experience of the staff but wages lower lecturer, training form is only to observe, so that the training effect is greatly reduced.

B. The special nature of accounting work, training base outside the establishment of difficulties.

Accounting information is confidential, many companies are not willing to let the external personnel contact the enterprise accounting information. If enterprises and vocational colleges accounting professional cooperation, and establish the training base, means that enterprises should provide many unknown information. So, When higher vocational colleges actively associated enterprises to conduct school-enterprise's accounting professional training base. cooperation, enterprise performance is not positive, in most cases it is the school of one-sided enthusiasm. At the same time, technical accounting work determines the students as a novice can not bear the task of accounting, to practice with 
special training, but each accounting staff of the enterprise to take a part of accounting work must spend extra time and energy if they guide a student, therefore, the enterprise accounting personnel also did not have the initiative to guide the students. In addition, accounting positions itself can accommodate staff co. For general enterprises, the accounting department set up the accounting post at least 1-2, many more than 10 , may not need a large number of staff as primary production or sales department, office space up to 23 office, some companies on the central office in a big office. Therefore, even if the enterprises to establish a training base, one can only accept a few students training, training only one training base can not solve the problem of school each year hundreds of students.

At present, China's actual situation in higher vocational colleges is an average school hundreds of students a total of only a few training base, this quantity can not meet the needs of students Professional practice. Author of Zheng Zhou vocational training base number and the training base of the use and training content to do the basic survey, total Investigation 20 vocational colleges, the survey results as shown in the following table.

Table 1 The off-campus training bases construction

\begin{tabular}{|l|c|c|c|c|}
\hline $\begin{array}{l}\text { Training base } \\
\text { number }\end{array}$ & $1 \sim 3$ & $3 \sim 5$ & $5 \sim 7$ & $7 \sim$ \\
\hline Many times & 14 & 2 & 3 & 1 \\
\hline Frequency & $70 \%$ & $10 \%$ & $15 \%$ & $5 \%$ \\
\hline
\end{tabular}

Table 2 Use the off-campus training bases

\begin{tabular}{|c|c|c|c|c|}
\hline $\begin{array}{l}\text { Training } \\
\text { times }\end{array}$ & 0 times & 1times & 2times & $\begin{array}{l}\text { More than } 2 \\
3 \text { times }\end{array}$ \\
\hline Many times & 0 & 12 & 5 & 3 \\
\hline Frequency & 0 & $\%$ & $25 \%$ & $15 \%$ \\
\hline
\end{tabular}

From the survey results can be seen, most of the training base construction of vocational colleges are in 3 , the average practice base to accommodate 42 students, this number is more than the number of internships can accept enterprise. From the use of practice base, accounted for more than $60 \%$ of the schools were not effective by practice base, most schools are only arranging students a training for several weeks, This training effect is not ideal.

\section{School-enterprise cooperation, lack of long-term operation mechanism, the enthusiasm of enterprises is not high.}

At present, many higher vocational colleges and business negotiation building practice base, often just "get", and do not want to "give", How to find the interests and win-win point of school and enterprise, the result is not established practice base breakdown in negotiations, is to establish relations of cooperation with enterprises short only. Because the students are lack of understanding of the corporate culture, labor discipline and business process, enterprise short receiving students into practice, enterprises must assign the daily management and business counseling, not only disrupt the normal working order, but also pay a lot of labor costs and management costs, increase the burden of the enterprise. In the process of guiding students to practice, the author is in charge of communication and leadership and accounting institution, that some of its real idea. Although some enterprises because of the sensibilities of receiving the students to practice, but if the training schools and students will only enterprise as the test site free of charge to "training", the enterprise is not welcome.

\section{Some built outside practice base, Don't let the} students practice in the specific business, only to arrange for students to do some simple office work, do not practice the true meaning of the post.

The reason is that the training base is facing many difficulties in carrying out training activities. First of all, enterprise accounting personnel to guide students to practice difficulties. Students after the enterprise is facing the real work environment and economic operation, the enterprise may not be the actual economic business accounting to the students, therefore, need enterprise has experienced accountant to served as instructor. But the enterprise accounting personnel after all to complete their tasks, and they have The lack of teaching organization and training in logic because they have no the teaching skills. so it is difficulty to pass the core skills and experience in a short period of time to the students

Secondly, there exits difficulties in training content and the arrangement of training evaluation. Because of higher vocational colleges are generally in the school built the accounting simulated training room and computerized accounting training room, and a lot of manual accounting and financial software processing business training, for students of accounting vouchers filling, the registration books and financial statements, financial software application is already quite familiar, But the teacher may be give them the repetition of these contents to the students because they are not familiar with the students, thus affecting the training effect. In addition, the students' training assessment, teacher to student more qualitative evaluation, quantitative aspect, this may with greater subjectivity and arbitrariness, can not really promote the students to improve skills. Finally, the difficulties in the management of students off-campus training period.

In fact the off-campus training bases more schools in order to meet the assessment, inspection, casually looking for a few companies hang on the name of the practice of enterprise, and did not play a substantive role, practice is often a mere formality. To the editor's school as an example, our students will be for a period of three weeks of training in the fifth semester, according to the feedback, the effect is not ideal, Because the students reflect most of the time they stay practice has done a lot of content in practical training in the company, really go out to do business time is very few, only a few times were arranged to tax office with the tax would simply look at the process. The other students in the training base for training time is short, some arrangements for a semester, some colleges and universities are less, the school is three weeks, it will appear the students began to face the 
end of our training, Thus, firms are more reluctant to spend a lot of time and energy to take care of this piece was not a profitable business. The writer made a simple survey about the training base utilization in three years of 20 colleges and universities, According to the results of the survey in three years, Training times these 20 colleges were carried out for 42times, Each training form as shown in the following table.

Table 3 The content of training practice base

\begin{tabular}{|l|c|l|l|l|}
\hline $\begin{array}{l}\text { Training } \\
\text { contents }\end{array}$ & $\begin{array}{l}\text { Profession- } \\
\text { ally active }\end{array}$ & $\begin{array}{l}\text { Some } \\
\text { post }\end{array}$ & $\begin{array}{l}\text { observe the } \\
\text { training }\end{array}$ & $\begin{array}{l}\text { Simulate } \\
\text { entraining }\end{array}$ \\
\hline $\begin{array}{l}\text { Many } \\
\text { times }\end{array}$ & 4 & 15 & 16 & 7 \\
\hline Frequency & $9.5 \%$ & $35.7 \%$ & $38 \%$ & $16.8 \%$ \\
\hline
\end{tabular}

According to the 20 schools of practice training base can be seen in the departments of the institutions of higher vocational training base is a simple extension of school training and did not play to the real on-the-job training role.

\section{ON THE CONSTRUCTION OF TRAINING BASES}

\section{A. Relying on the higher vocational colleges, to create a} financial company by the double accounting teacher partnership

In this mode, the company can undertake external financial management consulting, agency bookkeeping, tax agent business and so on, Compared with the usual economic business can be under the guidance of teachers. This is true also established the real practical training base for students' and the same time, it can also bring a certain income for schools, and the students can also get some incomes their enthusiasm will be greatly enhanced, application to shorten and enterprises docking platform and makes the content updates can be faster to the reality, this training base has the sustainability and keep innovation. The training program shall be formulated jointly by the school, enterprise and practice guidance teachers refer to the following table。

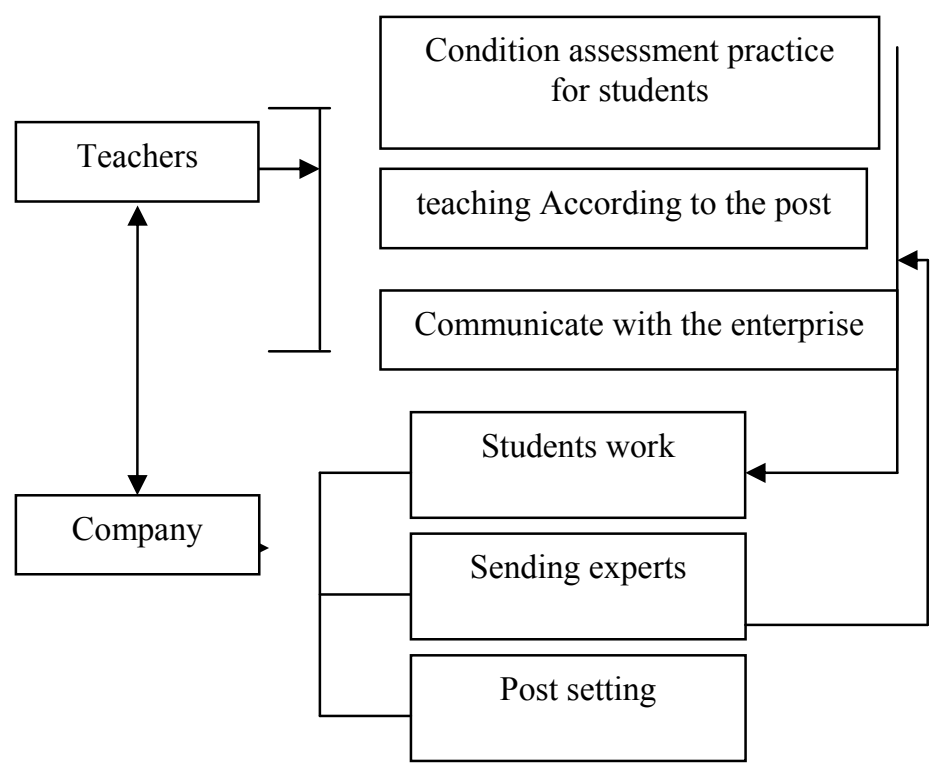

\section{B. The formation of joint training center}

Because of the higher vocational colleges of funds, repetitive training room construction, it is a waste. So it can be led by vocational accounting teaching force, combined with other higher vocational colleges construction investment has a "joint venture" nature of the training center. The training center not only can solve the practical problem that few students in higher vocational colleges, but also can provide accounting training, training for the secondary vocational school and social youth service. This can play the demonstration and radiation effect, but also through the appropriate charge to maintain the operation of training center. Through the information network to realize information sharing, training in higher vocational colleges, improving training level, to cultivate more talents for the society.

\section{Through the "order class" mode, establishing training bases}

The school can cooperate with some companies, training plan jointly formulated "order class".

the company puts forward the future need what talents, what course should be studied through the Consulting together between the schools and companies. these contents are reflected in the talent training plan. In addition to school teachers in classroom teaching, also invited experts to give lectures. Students can go company, If the number of students more, arrange, Company and its business units, to admit more students to other units to practice.

\section{Cooperate with CPA firm, Accounting Firm, establishing training bases}

Cooperation with the accounting firm, the Accounting Firm of this type of unit, set up training bases, On one hand because of the accounting business the unit of work has fluctuations, less time, on the other hand, these units need to expand the business, coupled with the accounting personnel mobility, so a period of accounting personnel demand. The school through the development of flexible teaching plans, these units can be in large volume of business or temporary needs a large number of accounting personnel, arrange students to these units to practice, not only solve the unit as pressing danger, also can let the student obtain internship opportunities.

\section{E. Analysis of the various characteristics of the enterprises, to find the right partner, eventually achieve the win-win.}

For the production of enterprises, because the accounting information is confidential information, are generally not willing to provide to outsiders, therefore, only accept $1-2$ students to practice. Therefore, can consider to establish links with a number of production enterprises. The accounting firm, the main business is to audit the enterprise accounting statements, the audit work mainly rely on the accounting professionals to complete, Therefore, accounting firm demand for accounting personnel more, And because the CPA business is busy, heavy workload, staff job-hopping frequently, CPA firms should become one of the main goals 
of establishing training bases. For the financial management of the company, its main business is to small and mediumsized enterprises accounting, bookkeeping, tax, industrial and commercial inspection, verification, this work needs more accounting talents. Therefore, the Accounting Firm also should establish the main goal of stable contact. At the same time, the accounting firm and the Accounting Firm's clients come from various industries, students could be familiar with many industries through the practice after the nature of business and accounting handling characteristics, thereby increasing employment opportunities.

\section{F. Making practice process, strengthen the management and assessment}

Off-campus practice base construction should establish and implement the "training base construction management approach", "the practice of assessment" and a series of training base management system, formulate suitable theoretical teaching and practice training plan, practice, practice guidance outline of training assessment method of practice teaching plan management, strict operation rules, strive to achieve reasonable personnel structure, clear job responsibilities, to ensure the systematic, scientific training base outside the operating orderly and construction management work. School-enterprise cooperation assessment process shown in the table below.

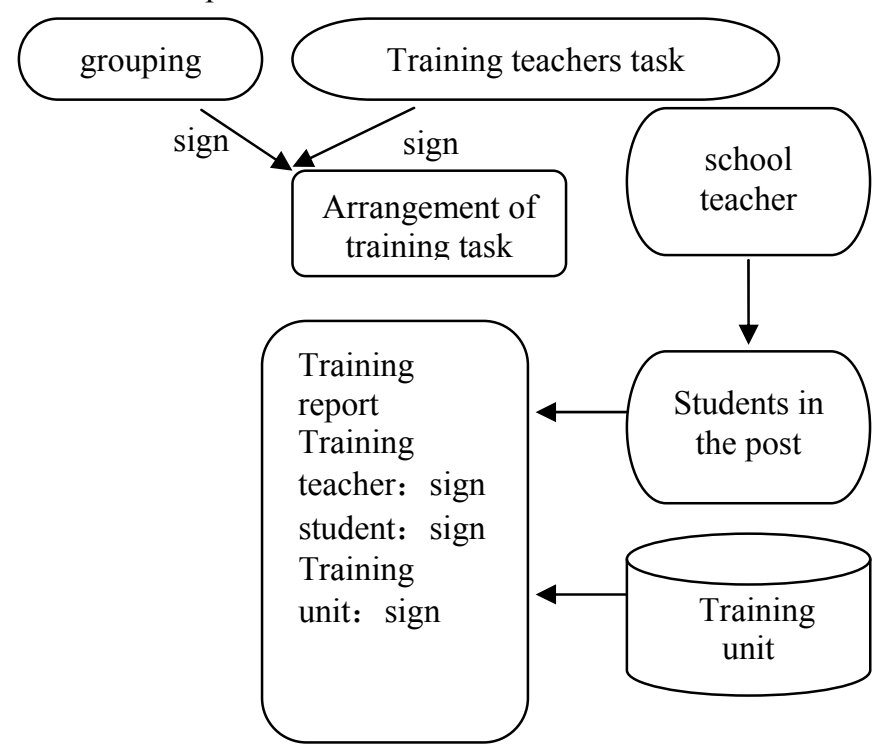

Accounting is a practical, open and occupation of special industry, To cultivate outstanding graduates, We must strengthen the construction of accounting training base. Through the joint efforts of school and enterprise, create a good social and economic benefits of the new base.

\section{REFERENCE S}

[1] Zhiyong $\mathrm{Fu}$, "Discussion on the construction of the accounting profession of internal and external training base in Higher Vocational Education", Small and medium-sized enterprise management and technology, pp. 251, September 2011. (references)

[2] Min Yang, Difficulties and Countermeasures of accounting specialty of higher vocational training base construction., Communication of Finance and accounting., Wuhan: 2008, pp.58-60.

[3] LinQin, "Research on the construction of practice bases of accounting major in Higher Vocational Colleges" Management informatization in China, Changcun, 2009, pp. 124-126.

[4] XiaoqingZheng, "Thoughts on strengthening the construction of training base of accounting major in Higher Vocational Colleges" Management informatization in China, Changcun,2012, pp. 118.

[5] XiaohongZhang, "Problems in construction of higher vocational accounting professional training base outside the crack" ,Friends of accounting,Tai Yuan,2009,pp.84-85.

[6] ShuwuSong, "Research on the construction of accounting professional training base in Higher Vocational Colleges under the new situation" Rich technologyguide,Jiyuan,2012,pp.5. 